\title{
New Archaeological sites in the Gulf of Cambay, India
}

\author{
National Institute of Ocean Technology, Chennai, India
}

India, with a coastline of over 7,500 km, is known to have engaged in maritime trade from the second half of the first millennium $B C$. Geophysical surveys conducted off the coast of Bombay, Laccadives, Tranquebar, Kutch, Cambay, Kaveripattinam and Visakapatnam have recorded shipwrecks, submerged cities, ports and channels. It is highly probable that the shelf off the Andhra, Kerala, Gujarat and Tamil Nadu coasts, if properly surveyed, will yield not only vestiges of prehistoric man and his tools but also submerged river channels and ports. A preliminary survey of the Gulf of Cambay with side-scan sonar soundings and a sub-bottom profiler revealed unnatural features. Further exploration through dredging brought to light artefacts that bore testimony to human activity.

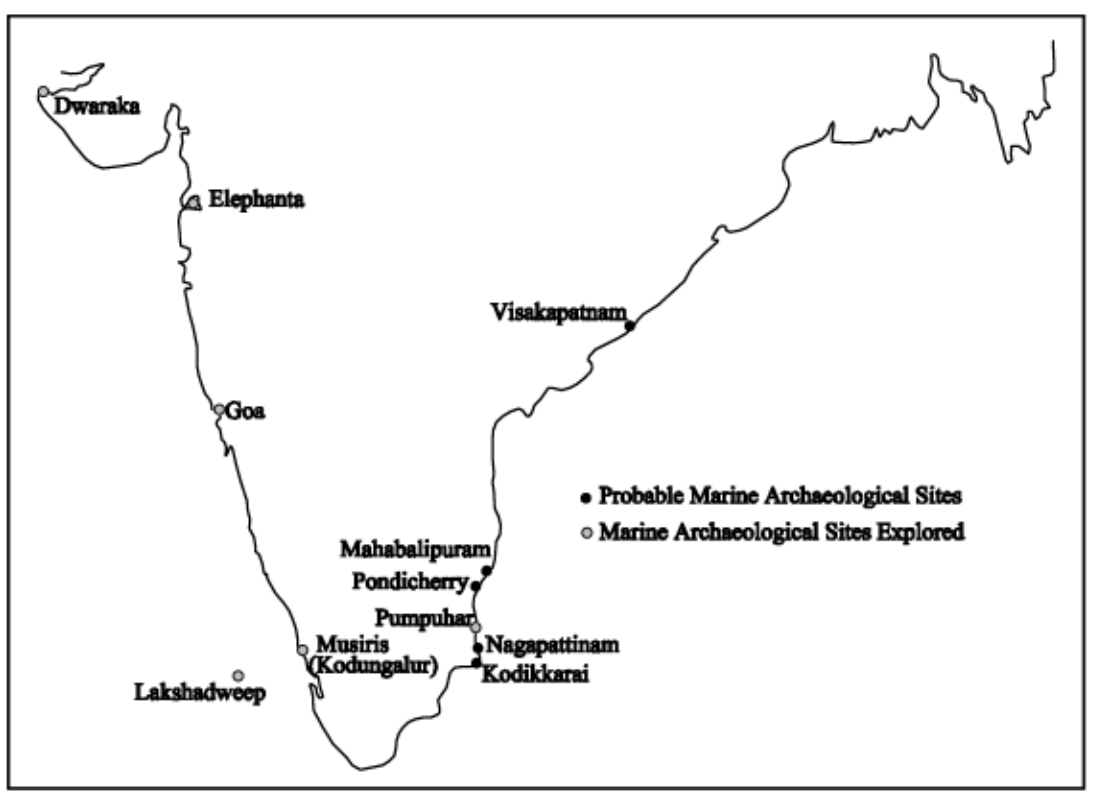

Figure 1 Known marine archaeological sites in India.

\section{Introduction}

Recent exploration of a part of the 7,500-km-long Indian coast indicated the presence of some marine archaeological sites, including those near Dwaraka, Elephanta Island (Roman wharf-cum-jetty) west of Mumbai (Rao, 1988), off Goa (Chauhan et al., 1988), near Kodungalur on the mouth of the Periyar River (previously known as Musiris) on the west coast (Rajan, 1988); and at Pumpuhar (Rao et al., 1988) and off Mahabalipuram, on the east coast. Other possible marine archaeological sites on the east coast include those at Kodikkarai, Nagapattinam, Pondicherry, and off Visakapatnam (Figure 1).

There is historical or literary evidence for almost all these sites, and they are traceable to the sea coast. The sites at Dwaraka, Elephanta, Musiris and Pumpuhar have been studied in detail, and bear testimony to the fact that several sites on the Indian coast got submerged when the sea level rose either due to glacial melting or tectonic causes (Rao, 1988). In the case of Dwaraka, the tectonic events are well known, and even the +8 magnitude earthquake with its epicentre near Bhuj on 26-1-2001 left an impact. This affected other parts of the Kutch and Cambay areas (Gupta et al., 2001).

In the case of Kodungalur (Musiris), a wellknown port which existed prior to $1341 \mathrm{AD}$ was submerged following a major earthquake (Ballore, 1904). For Pumpuhar and Mahabalipuram off the east coast there are historical references. The area was inundated, submerging several existing structures (Rao et al., 1988).

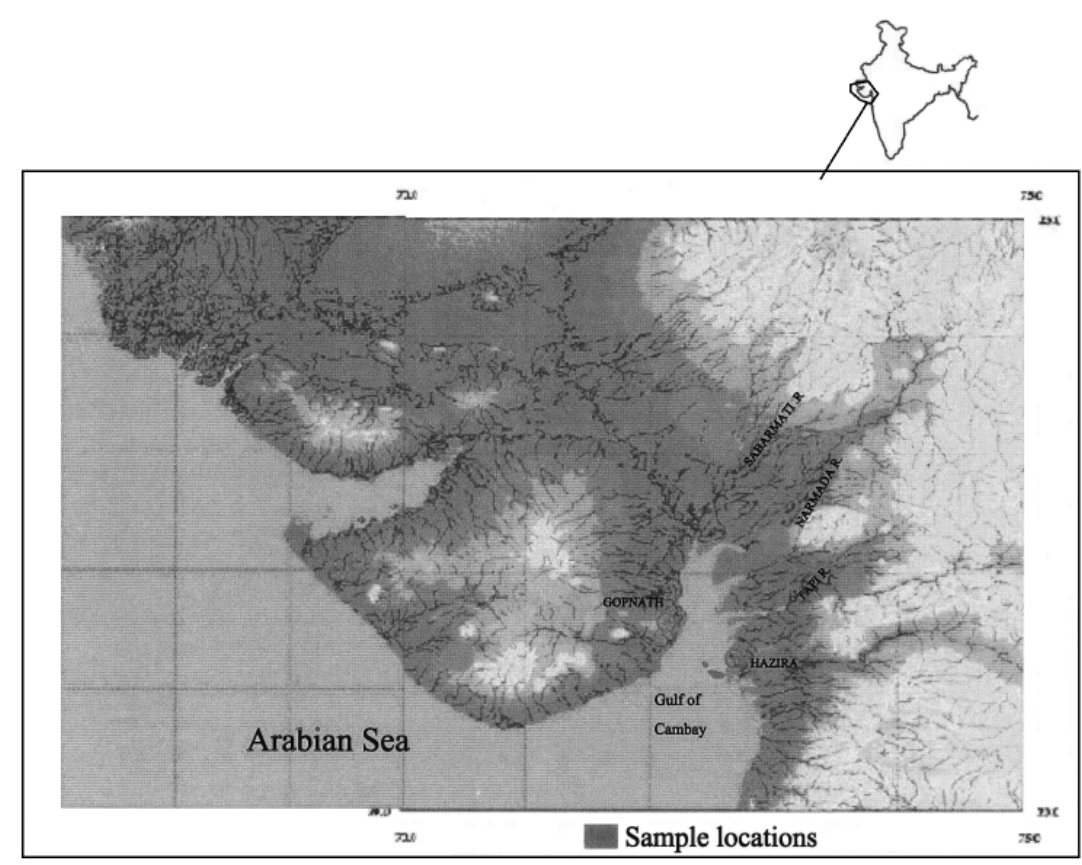

Figure 2 Marine archaeological site in the Gulf of Cambay.

The National Institute of Ocean Technology (NIOT), the technical arm of the Department of Ocean Development, Government of India, has been carrying out several off-shore surveys for various purposes including pollution monitoring, harbour engineering, pipeline laying, construction of offshore structures, etc. In 2000, dur- 
ing the course of surveys in the Gulf of Cambay, NIOT recognized a series of geometric patterns picked up by side-scan sonar soundings which are very unusual in the marine domain. Repeated surveys of these features clearly picked up a palaeochannel-like feature over 9 $\mathrm{km}$ long. In order to substantiate these findings, NIOT carried out detailed sub-bottom profiling in the area. The features occur at depths of between 20 and $40 \mathrm{~m}$ in the Gulf of Cambay about $20 \mathrm{~km}$ west of Hazira (Figure 2). There are no known references in the literature to this site. This discovery was made by analysis of advanced underwater sensors like side-scan sonar, sub-bottom profiler and multi-beam echo sounder. Here we present some aspects of this marine archaeological discovery.

\section{Geological setting}

The Gulf of Cambay is located in the southwestern part of the State of Gujarat, and is an arm of the Arabian Sea, covering over 3,000 sq km. Several rivers, including the Narmada, Tapti, Sabarmathi and Mahi, drain into it. Almost all the rivers have preferred directions of NE-SW, ENE-WSW or NNE-SSW. These rivers form an estuarine complex.

In the Gulf of Cambay there are several long linear sandy shoals which rise predominantly from the surrounding clayey formations. These shoals are known to shift their locations periodically and cause uncertainties in the sea bed bathymetry and hence for navigation. An examination of the earlier topo-sheets with the later National Hydrographic Charts and the LANDSAT imageries indicates the growth of landforms like bars, levees, mud flats, islands, etc. The area has three major faults (Merh and Chamyal, 1997), designated as the Cambay graben fault trending in a N-S direction, west coast fault along NNW-SSE direction on the east coast and the approximately EW-trending Narmada geofracture. Neotectonic activity in this region appears to have disrupted river courses from time to time. The area experiences periodic earthquakes and tremors, and scrutiny of them reveals that the surrounding areas like Bharuch, Bhavnagar, Surat, Dumas, etc., are often the epicenters of these seismic events. This being a well-known macro-tidal regime with a tidal range of $12.5 \mathrm{~m}$ and with a current speed of up to 8 knots, turns the sea state from rough to very rough. Due to these factors, the waters of the Gulf of Cambay are heavily silted, brownish in colour and highly turbid. Such conditions impose severe restrictions on surveys and the understanding of the geology of the area. The Cambay Sea extends over $80 \mathrm{~km}$ in width between Gopnath point $\left(21^{\circ} 11^{\prime} 8^{\prime \prime} \mathrm{N}\right.$ $\left.72^{\circ} 06^{\prime} 37^{\prime \prime E}\right)$ in the west and Hazira $\left(21^{\circ} 4^{\prime} 35^{\prime \prime} \mathrm{N} 72^{\circ} 37^{\prime} 31^{\prime \prime E}\right)$ on the east coast. The detailed survey by NIOT revealed that the Gulf of Cambay has an alternating sand and clay formation on the seabed. In order to understand the occurrence of the palaeochannel in the middle of the Gulf of Cambay, some cores were taken by vibro- and gravity-coring operations. These revealed that in the palaeochannel area the sea bed surface and a section up to about $0.7 \mathrm{~m}$ depth is made up of medium sand with marine shells representing marine facies. This is followed, at depths of 0.70 to $2.20 \mathrm{~m}$, by a sand and silt formation containing freshwater shells representing alluvial facies ( fluvial regime) and archaeological material. At this depth there is a sharp contact with pebbly conglomerate representing fluvial facies lying below. As we go deeper, a sharp contact with calcareous sandstones with rhizoliths is found at depths varying from 3 to $4 \mathrm{~m}$. The last one represents buried land surface.

Several of the calcareous sandstone samples collected had regular circular or rectangular perforations. A thin section study of these under the petrological microscope shows that well-rounded goethite grains constitute about $25 \%$ of the material, with sizes ranging from 80 to 110 microns. About an equal percentage of the detrital grains seems to be angular to sub-angular quartz with a size range of 40 to 60 microns. The remaining cementing material is mostly made up of calcite. Apart from this, a few foraminifera, textularids, sponges, echnoid spicules and few ostrocod skeletal remains are found. The rock apparently represents a fluvio-marine environment which subsequently became water-cemented probably due to the lowering of the ground water level in the area. This is evidenced by the formation of root casts and rhizoliths. The calcareous sandstone indicates an ancient land surface on which fluvial and human activities took place.

The conglomerate mainly consists of basalt, chalcedony and litho-clasts of calcareous sandstone, and represents a high-energy fluvial system. Similar conglomerates were observed below the early Harappan settlement at Padri on land on the western side of the Gulf of Cambay (Rajaguru, 2002).

\section{Archaeological findings}

The side-scan sonar images have picked up rectangular basements like feature on either side of the palaeochannel with a relief of 2 to 3 $\mathrm{m}$ from the seabed and vary in size from $5 \times 5 \mathrm{~m}^{2}$ to as much as $15 \times$ $15 \mathrm{~m}^{2}$. These features are often covered by sand waves. At places basements of possibly major structures have been picked up (Figure $3)$. The sub-bottom profiler survey clearly revealed successive layers made up of foundation-like features and cultural strata indicated by acoustic impedance contrast below the basement.

The sites identified by side-scan survey were subjected to sampling by a Van-Veen grab sampler, dredge sampler, and by gravity and vibro corers. Quite a few artefacts of archaeological importance have been recovered from these sites, which are absent outside the area adjoining the palaeochannel. The artefacts identified included many beads, of which a broken barrel-shaped bead of chert (Figure $3 \mathrm{a})$, measuring $13 \mathrm{~mm}$ in length and $6 \mathrm{~mm}$ in width and with a $4 \mathrm{~mm}$

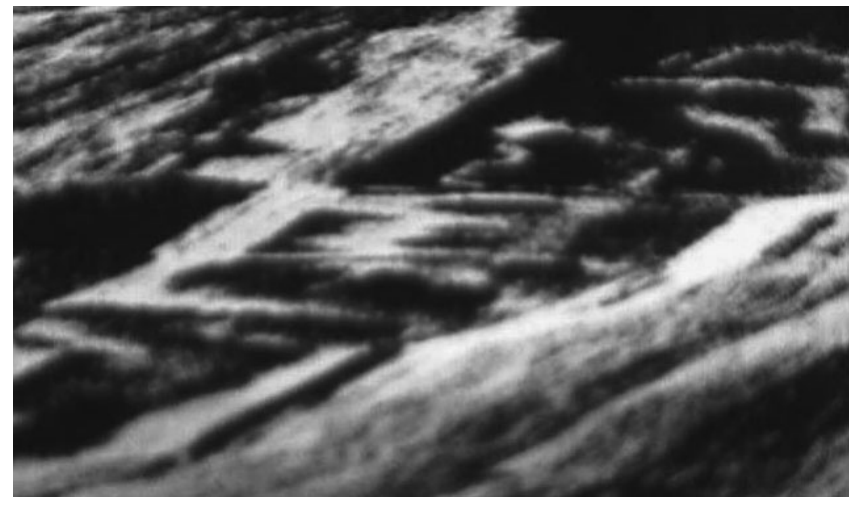

Figure 3 Sonogram of a major structure.

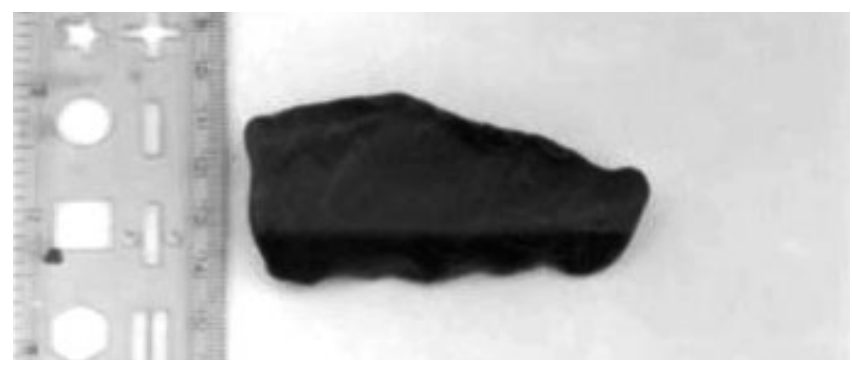

Figure 3a Chert barrel bead (broken).

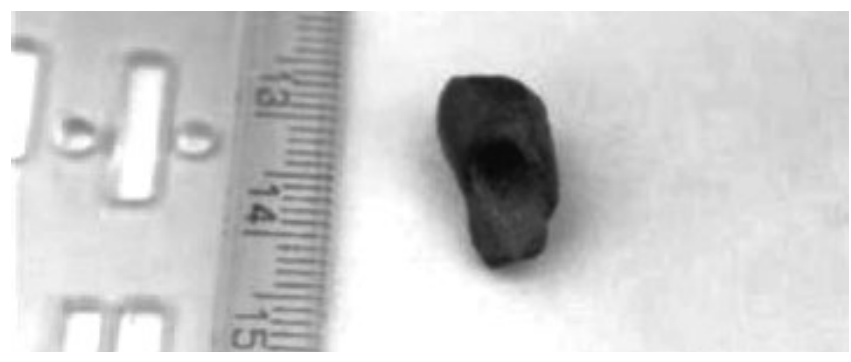

Figure $3 b$ Chert blade scraper. 
diameter hole, is important. As per Gosh (1989), the tradition of making beads is at least 7000 years old. A chert blade scraper (Figure $3 \mathrm{~b}$ ), measuring $76 \mathrm{~mm}$ in length, with a width varying from 35 $\mathrm{mm}$ to $19 \mathrm{~mm}$ and with a thickness of $10 \mathrm{~mm}$, typologically belonging to the upper Palaeolithic cultural tradition, was also recovered. Low-fired and grass-embedded pottery pieces were recovered, along with broken hearth material. The piece appears to be made of fine, well levigated clay and is about $3 \mathrm{~mm}$ across. The perforated stone piece was examined under an optical image analyzer. The examination revealed, in $100 \mathrm{X}$ magnification, that the holes are irregularly oval in shape and have varying contours. This appears to be connected with deliberate boring activity by a stone tool like a borer, which was quite common in the prehistoric period.

In addition, quite a few human bones, as well as a few teeth, have been recovered from the area.

\section{Chronology}

A piece of carbonized wood $30 \mathrm{~cm} \times 15 \mathrm{~cm}$ in dimension was recovered in the sand-silt zone in the alluvial facies, and subjected to radio-carbon dating. The National Geophysical Research Institute (NGRI) in Hyderabad gave the carbon date as 8592 ( 235 years BP and a calibrated age of BP 9544 (range 9910-9331). The Institute of Earth Science in Hanover, Germany, gave a carbon age of 8510 (55 years and the calibrated age as 9545 years BP. The presence of dead coral and the fact that the area appears to have been inundated by marine transgression is consistent with the radio-carbon dating. A similar submergence of corals in other parts of the world due to influence of glacial melting concurs well with the observations made here (Fairbanks, 1989, Bard et al., 1987).

\section{Conclusion}

In view of this strong evidence, it can be stated that there was human habitation in the area along the then existing river channel, which appears to have been inundated by marine transgression, probably caused by sea level rise and tectonic events in the area. The evidence provided by NIOT in the Gulf of Cambay has prompted the Government of India to set up a 'National Team' to probe the area further to unravel the details of these exciting marine archaeological findings. The details of the discovery are expected to change the present view of the prehistory of India and its environs.

\section{References}

Ballore, M. de., 1904,Memoirs of the Geological Survey of India., vol. XXXV,p. 3

Bard Edouard, Maurice Arnold., Pierre Maurice., Josette Duprat., Jean Moyes., and Jean-Claude Duplessy., 1987, Retreat velocity of the North Atlantic polar front during the last deglaciation determined by ${ }^{14} \mathrm{C}$ accelerator mass spectrometry, NATURE, v. 328, pp. 791-794.

Chauhan, O. S., and Almeida, F., 1988, Geophysical methods as a tool to explore submerged Marine Archaeological sites. Proceedings of the first Indian Conference on Marine Archaeology of Indian Ocean Countries, October 1987, NIO, Goa, pp. 3-4.

Gosh, A., 1989, Encyclopaedia of Indian Archaeology, Munshiram Manoharlal, New Delhi, pp. 39, 216.

Gupta, Harsh .K., Purnachandra Rao., Rastogiri, N., and Dipankar Sarkar., 2001, The Deadliest intraplate Earthquake, Science, March 16, pp. 21012102 .

Merh, S. S., and Chamyal, L. S., 1997, Quaternary Geology of Gujarat Alluvial Plain, Proceedings of the Indian National Science Academy, $63 \mathrm{~A}$, no.1, pp. 1-98.

Rajaguru, S. N., 2002, Quaternary geoarchaeological background of western coastal margin of the gulf, Proceedings of the marine archaeological workshop, National Institute of Ocean Technology, Chennai, pp. 1-2.

Rajan, K., 1997, A Port of Musiri, Journal of Marine Archaeology, NIO, Goa, v. J-6, pp. 49-52.
Rao, S. R., 1988, The future of Marine Archaeology in Indian Ocean countries, Proceedings of the first Indian Conference on Marine Archaeology of Indian Ocean Countries, October 1987, NIO, Goa, pp. XXI-XXV.

Rao, S. R., Vora, L. H., Gaur, A. S., Gudigal, P., Sundaresh., and SilaTripathi., 1997, A preliminary shipwreck exploration off Lakshadweep, Journal of Marine Archaeology, NIO, Goa, v. 5-6, pp. 23-31.

Rao, S. R., Rao T. C. S., Gaur, A. S., Sila Tripathi., Sundaresh., and Gudigar, P., 1997, Under water explorations off Poompuhar, Journal of Marine Archaeology, NIO, Goa, v. 5-6, pp. 7-17.

Richard, G. Fairbanks., 1989, A 17000-year glacio-eustatic sea level record: influence of glacial melting rates on the Younger Dryas event and deepocean circulation, Nature, v.342, pp. 637-642.

Dr. S. Kathiroli obtained M. Tech from IIT (Kanpur) in India in 1981. Received his Ph.D. in Maritime Engineering from University of Liverpool U.K. in 1988. He worked at Regional Engineering College, Calicut as Associate Professor and presently heading Coastal and Environmental Engineering Group in NIOT, Chennai, India. He has 20 years of experience in ocean engineering from both academic institutions and consultancy organisations. His field of specialization is marine field investigation and offshore structures designs.

S. Badrinarayanan did his M. Sc. from Madras University in 1961 in India. He has more than 40 years of professional experience in the onshore and offshore geological investigations including for several minerals, for ground water and for various engineering geological problems. Carried out more than 60 marine geotechnical investigation and at present associated with NIOT, Chennai as a consultant for offshore consultancy investigations.

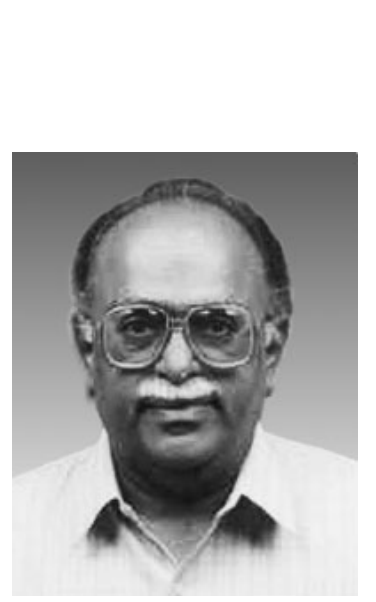

D. Venkata Rao obtained M. Sc. (Tech) from Andhra University in India in 1970. He received training in marine seismic and seismic stratigraphy from Amsterdam Free University, Holland during 19821983. He worked in Geological Survey of India as Geophysist for about 27 years and at present works as a Senior Scientist in NIOT, Chennai, India. He has carried out more than 100 geophysical investigation both on land and in offshore regions. He has extensively worked for many offshore development projects all along in Indian Coast.
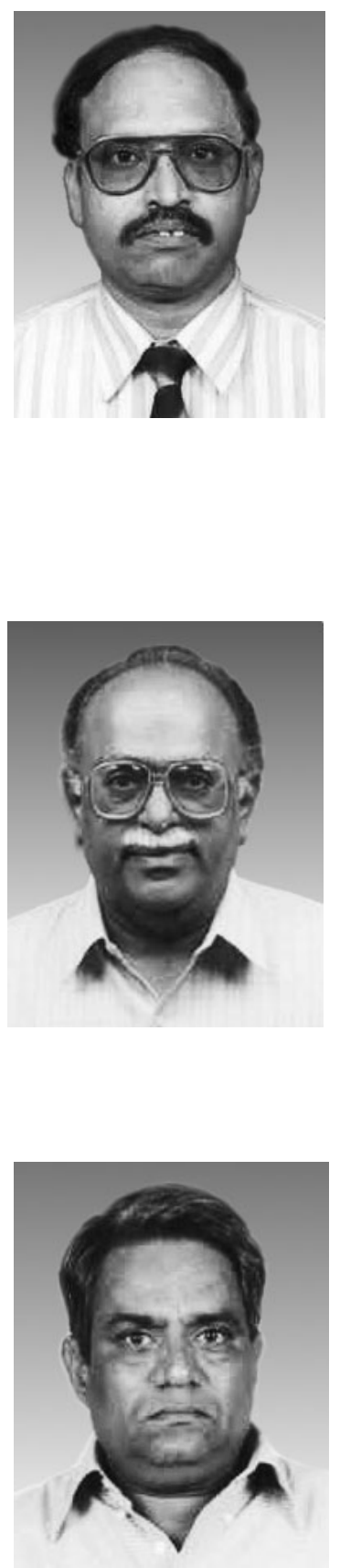